\title{
TELAAH FILSAFAT PENDIDIKAN ISLAM DAN IMPLIKASINYA TERHADAP PENDIDIKAN SEUMUR HIDUP MENUJU MASYARAKAT MADANI
}

\author{
Iwan Israwan \\ Sekolah Tinggi Bahasa Asing (STBA) Sebelas April Sumedang, Indonesia \\ Email: iwanisrawan2018@gmail.com
}

\begin{abstract}
Abstrak
Masyarakat madani pada bidang pendidikan ialah penyiapan sumber daya manusia yang berwawasan dan berperilaku madani melalui pendidikan, karena konsep masyarakat madani merupakan bagian dari tujuan pendidikan nasional. Semua pihak barangkali setuju, bahwa pendidikan amat penting bagi ikhtiar membangun manusia berkualitas, yang ditandai dengan peningkatan kecerdasan, pengetahuan dan keterampilan, karena pendidikan sendiri merupakan wahana strategi bagi usaha untuk meningkatkan mutu kehidupan manusia, yang ditandai dengan membaiknya derajat kesejahteraan, menurunnya kemiskinan, dan terbentuknya berbagai pilihan dan kesempatan mengembangkan diri menuju masyarakat madani. Permasalahan yang dihadapi pendidikan seumur hidup sangatlah komplek. Berbagai kebijakan telah diprogramkan oleh pemerintah Indonesia namun dalam tataran implementasi masih banyak kendala terutama mental masyarakat yang kurang termotivasi, sehingga pada akhirnya pendidikan kurang mampu dioptimalkan sebagai lembaga yang mendapat dukungan masyarakat luas. Oleh karenanya masyarakat madani menjadi sangat penting untuk dikaji ulang. Tujuan penelitian untuk menelaah filsafat pendidikan Islam sebuah telaah kritis terhadap suatu konsep filosofis, interpretasi tentang pendidikan Islam dan implikasinya terhadap pendidikan seumur hidup. Metode penelitian dengan pendekatan filsafat dengan mencari hikmah atau kebijaksanaan juga kebenaran. Peneliti menelaah secara kritis bahwa: "Pendidikan seumur hidup adalah suatu proses penyempurnaan perkembangan pribadi, pengembangan sosial dan keahlian selama jangka waktu hidup dari individu untuk supaya menambah (meningkatkan) suatu kehidupan baik bagi pribadi-pribadi maupun kelompoknya. Ini adalah suatu gagasan yang komprehensif (luas, lengkap) dan integratif (serupa, sama), yang mencakup belajar informal, formal dan nonformal untuk tujuan keahlian dan pencerahan agar tercapai perkembangan sepenuhnya pada setiap tahapan dan lapangan hidup. Hal ini bila dihubungkan dengan keduanya baik pertumbuhan pribadi dan kemajuan masyarakat". Secara khusus bertujuan ingin melihat secara lebih dalam mengenai landasan filosofis pendidikan Islam dan implikasinya terhadap konsep pendidikan seumur hidup menuju masyarakat madani. Berdasarkan hal itu, maka kesimpulan dalam tulisan ini adalah terdapat beberapa landasan pokok yang dapat dijadikan sebagai bangunan dasar untuk memahami tentang hakikat pendidikan Islam. Hasil penelitian, Filsafat Pendidikan Islam beranggapan bahwa pendidikan yang tidak mempunyai tujuan yang mencerminkan kepribadian suatu bangsa, maka apa yang akan dicita-citakan oleh bangsa tersebut untuk menuju masyarakat madani tentu akan mengalami kegagalan. Filsafat Pendidikan Islam memiliki dasar yang kuat, strategis dan fungsional dalam upaya membangun masyarakat madani. Dalam tulisan ini, penulis akan memaparkan telaah filsafat pendidikan seperti apakah yang ditawarkan oleh Islam dalam mewujudkan masyarakat madani.
\end{abstract}

Kata Kunci : Masyarakat Madani; Pendidikan Seumur Hidup; dan Filsafat Pendidikan Islam. 


\section{Abstract}

Civil society in the education aspect is the preparation of human resources with knowledge and civilian behavior through education. It is because the concept of civil society is part of the national education goal. All people may agree that education is important for building human quality, indicated by improving intelligence, knowledge, and skills since education is a strategic sector for the quality of human life by developing in the degree of welfare, a decrease in poverty, and the formation of various options and opportunities to develop themselves towards civil society. The complex problem in lifelong education is faced. Various policies have been made by the Indonesian government. However, in terms of implementation, it is found many obstacles, particularly in the mentality of the people who are lack motivation, so the education cannot be optimized as an institution that has broad community support. Therefore, civil society is important to be reviewed. The research objective is to examine the philosophy of Islamic education as a critical analysis of a philosophical concept, the interpretation of Islamic education, and its implications for lifelong education. The research method used a philosophical approach by seeking a good lesson or wisdom as well as truth. Researchers examined critically that: "Lifelong education is a process of improving personal development, social development, and expertise during the life span of an individual to improve life for both individuals and groups. This is a comprehensive (broad, complete) and integrative (similar, same) idea, which includes informal, formal, and informal learning for expertise and enlightenment to achieve full development at every stage and field of life. This is related to both personal growth and social progress". In particular, it aims to look more deeply at the philosophical foundations of Islamic education and its implications for the concept of lifelong education towards civil society. Based on this, the conclusion in this paper is that several main bases can be used as a basic building for understanding the nature of Islamic education. The result shows that Islamic Education Philosophy views that education having no purpose that reflects the personality of a nation as what the country will reach will certainly fail. The philosophy of Islamic Education has a strong, strategic, and functional foundation in the effort to build civil society. In this study, the writer examines what kind of educational philosophy is offered by Islam in realizing a civil society.

Keywords: Civil Society, Lifelong Education, and Islam Education Philosophy.

\section{PENDAHULUAN}

Penelitian ini didorong praktek pendidikan yang selama ini cenderung kering humanistis perlu transformasi. Transformasi pendidikan dapat dilakukan apabila diyakini bahwa perubahan merupakan satu-satunya upaya untuk mencari cara baru dalam mengatasi masalah pendidikan. Cara kritis dalam menghadapi kendala reformasi pendidikan menuju mayarakat yang humanistis dapat dilakukan melalui praktek pendidikan yang berwawasan masyarakat madani.Pokok pikiran yang melandasi perubahan orientasi pada konsep-konsep humanistis dipandang perlu mempertimbangkan hal-hal sebagai berikut: (1) perlunya pemahaman kembali konsep pendidikan dan ilmu pendidikan (2) perlunya telaah pendidikan 
dan praktiknya dalam masyarakat (3) berorientasi pada terwujudnya pendidikan yang bermutu ${ }^{1}$.

Upaya untuk mewujudkan masyarakat madani yang demokratis memerlukan kerja keras dan komitmen dari seluruh masyarakat anak bangsa melalui pendidikan seumur hidup. Keberhasilannya banyak dipengaruhi oleh kerjasama menyeluruh antara pendidikan informal, nonformal, dan formal.

Sudah banyak telaah pendidikan seumur hidup yang dilakukan kalangan ahli pendidikan diantaranya menurut R.H. Dave (1976:343): "Pentingnya pendidikan seumur hidup sebagaimana yang digambarkan dari segi filsafat, bahwa pendidikan seumur hidup mencakup pusat seluruh sistem yang berdasarkan filsafat manusia dan pengembangan kreativitasnya" (an entire philosophical system centred upon man and his creative development). Ini berhubungan dengan kebutuhan yang sangat mendesak dan luas bagi manusia untuk mengatasi persoalanpersoalan masyarakat, yang sesungguhnya telah diciptakan manusia dan yang masih sedang diciptakan. Oleh karena itu, pendidikan seumur hidup mencakup seluruh cara kehidupan secara menyeluruh. Ini akan mencakup perubahan bentuk dan lain-lain baik bagi manusia pada umumnya maupun bagi masyarakat tertentu pada khususnya. Sebagai akibatnya, pendidikan seumur hidup itu sangat penting baik untuk individu, masyarakat, para pendidik dan politisi (pengambil kebijakan) itu sendiri. ${ }^{2}$

Prinsip penyelenggaraan pendidikan menurut Undang-undang Sistem Pendidikan Nasional Nomor 20 Tahun 2003 Pasal 4 ayat (3) dinyatakan bahwa "Pendidikan diselenggarakan sebagai suatu proses pembudayaan dan pemberdayaan peserta didik yang berlangsung sepanjang hayat" Kemudian mengenai hak dan kewajiban warga negara dalam Pasal 5 ayat (5) dikatakan: "Setiap warga negara berhak mendapat kesempatan meningkatkan pendidikan sepanjang hayat". Selanjutnya mengenai pendidikan nonformal Pasal 26 ayat (1) berbunyi: "Pendidikan nonformal diselenggarakan bagi warga masyarakat yang memerlukan layanan pendidikan yang berfungsi sebagai pengganti, penambah, dan/atau pelengkap pendidikan formal dalam rangka mendukung pendidikan sepanjang hayat". 3

Penjelasan atas Undang-Undang Republik Indonesia Nomor 20 Tahun 2003 tentang Sistem Pendidikan Nasional dalam kaitannya dengan pendidikan seumur hidup secara umum visi dapat dijelaskan sebagai berikut:

\footnotetext{
${ }^{1}$ https://jurnal.uns.ac.id/JRR/article/view/1182

2 R.H. Dave, (1973), Lifelong Education and School Curriculum, UNESCO Institute Monographs, Whole
} No. 1.

\footnotetext{
${ }^{3}$ Undang-Undang Sistem Pendidikan Nasional, (2003), UU RI No. 20, Jakarta, Sinar Grafindo.
} 
Manusia membutuhkan pendidikan dalam kehidupannya. Pendidikan merupakan usaha agar manusia dapat mengembangkan potensi dirinya melalui proses pembelajaran dan/atau cara lain yang dikenal dan diakui oleh masyarakat. Undang-undang Dasar Negara Republik Indonesia Tahun 1945 Pasal 31 ayat (1) menyebutkan bahwa: "Setiap warga berhak mendapat pendidikan", dan ayat (3) menegaskan bahwa: "Pemerintah mengusahakan dan menyelenggarakan satu sistem pendidikan nasional yang meningkatkan keimanan dan ketakwaan serta akhlak mulia dalam rangka mencerdaskan kehidupan bangsa yang diatur dengan undang-undang”. Untuk itu, seluruh komponen bangsa wajib mencerdaskan kehidupan bangsa yang merupakan salah satu tujuan negara Indonesia. ${ }^{4}$

Kehadiran pendidikan seumur hidup disebabkan oleh munculnya kebutuhan belajar dan kebutuhan pendidikan yang terus tumbuh dan berkembang sepanjang alur kehidupan manusia. Adapun masalah pendidikan seumur hidup itu penting bagi Indonesia adalah untuk menciptakan iklim belajar seumur hidup yang berbasis masyarakat, sehingga akan terjadi keterpaduan antara pendidikan keluarga, sekolah, dan masyarakat. Sistem pendidikan nasional semestinya berkembang menuju sistem pendidikan yang terpadu antara jalur sekolah (formal) dan luar sekolah (nonformal) yang memungkinkan masyarakat memiliki akses dan pilihan yang semakin luas dan fleksibel terhadap pendidikan. Keterpaduan sistem pendidikan nasional itu akan mendukung terwujudnya proses belajar seumur hidup (lifelong learning) dan masyarakat madani (civil society). Dengan cara itu, maka potensi-potensi masyarakat dapat tumbuh secara berkelanjutan.

\section{METODE PENELITIAN}

Metode yang digunakan dalam penelitian ini adalah metode penelitian kualitatif, dan metode berpikir reflektif secara filosofis. Intinya dimulai dengan studi pustaka. Untuk melengkapi keterangan dan bukti-bukti yang penulis kemukakan dalam penelitian ini, maka penulis membaca, meneliti, dan menelaah berbagai buku yang ada kaitannya dengan judul yang dibahas, yaitu studi terhadap beberapa literatur dari buku-buku, filsafat, pendidikan, pembelajaran, dan pengajaran. Dalam penelitian kualitatif diupayakan analisis isi menggunakan ukuran makna kata-kata, mengungkap hakikat dari suatu fenomena secara totalitas dengan menggunakan ketepatan interpretasi dengan ketajaman analisis, objektivitas, sistematik dan sistemik.

Sebagai ciri dari penelitian ini adalah dengan menggunakan lingkungan alamiah, yaitu

\footnotetext{
${ }^{4}$ Undang-Undang Dasar 1945 Amandemen (2002).
} 
melihat situasi pendidikan baik dalam lingkungan keluarga, sekolah, dan masyarakat sebagaimana adanya (alami). Peristiwa-peristiwa yang terjadi dalam situasi pendidikan tersebut di atas dilihat sebagai peristiwa sosial, interaksi manusia. Pendekatan filosofi terhadap pendidikan adalah suatu pendekatan untuk menelaah dan memecahkan masalah-masalah pendidikan dengan menggunakan metode filsafat. Pengetahuan atau teori pendidikan yang dihasilkan dengan pendekatan filosofi disebut filsafat pendidikan. Cara kerja dan hasil-hasil filsafat dapat dipergunakan untuk membantu memecahkan masalah dalam hidup dan kehidupan, dimana pendidikan merupakan salah satu kebutuhan penting dari kehidupan manusia. Pendidikan membutuhkan filsafat, karena masalah pendidikan tidak hanya menyangkut pelaksanaan pendidikan semata, yang hanya terbatas pada pengalaman. Dalam pendidikan akan muncul masalah yang lebih luas, kompleks, dan lebih mendalam, yang tidak terbatas oleh pengalaman inderawi maupun fakta-fakta faktual, yang mungkin tidak dapat dijangkau oleh sains pendidikan (science of education). Masalah-masalah tersebut diantaranya adalah tujuan pendidikan yang bersumber dari tujuan hidup manusia dan nilai sebagai pandangan hidup manusia. Nilai dan tujuan hidup memang merupakan suatu fakta, namun pembahasannya tidak bisa dengan menggunakan cara-cara yang dilakukan oleh sains, melainkan diperlukan suatu perenungan yang lebih mendalam (reflective thinking/reflection).

Tujuan pendidikan senantiasa berhubungan langsung dengan tujuan hidup dan pandangan hidup individu maupun masyarakat yang menyelenggarakan pendidikan. Pendidikan tidak dapat dipahami sepenuhnya tanpa memahami tujuan akhirnya, sehingga hanya tujuanlah yang dapat ditentukan terlebih dahulu dalam pendidikan. Tujuan pendidikan tersebut perlu dipahami dalam kerangka hubungannya dengan tujuan hidup tersebut, baik yang berkaitan dengan tujuan hidup individu maupun kelompok, si terdidik maupun pendidik secara pribadi memiliki tujuan dan pandangan hidup sendiri, dan sebagai masyarakat atau warga negara memiliki tujuan hidup bersama.

Karakteristik pendekatan filosofi, seperti halnya pendekatan sains, dapat dilihat dari objek pengkajian, tujuan pengkajian, dan metode kerja pengkajian. Objek pengkajian pendidikan dengan menggunakan pendekatan filosofi, adalah semua aspek pendidikan tidak terbatas pada salah satu aspek saja. Seluruh aspek pendidikan, seperti tujuan pendidikan, isi pendidikan, metode pendidikan, pendidik, anak didik, keluarga, masyarakat adalah merupakan kajian yang komprehensif dari pengkajian filosofi. Pengkajian seperti ini disebut pengkajian sinopsis, yaitu suatu pengkajian yang bersifat merangkum atau mencakup semua aspek pendidikan.

Tujuan akhir suatu pengkajian filosofi dalam pendidikan adalah merumuskan apa dan 
bagaimana seharusnya tentang pendidikan. Kajian filosofi berusaha merumuskan apa yang dimaksud dengan pendidikan, bagaimana seharusnya tujuan pendidikan, bagaimana seharusnya kurikulum dirumuskan/disusun. Pengkajian seperti itu disebut pengkajian normatif, karena berkaitan dengan norma-norma, nilai-nilai yang berlaku dalam kehidupan manusia, sehingga pengkajian tersebut harus sampai pada suatu rumusan, apa yang seharusnya terjadi dalam pendidikan yang berlangsung dalam kehidupan. Metode pengkajian filosofi adalah melalui kajian rasional yang mendalam tentang pendidikan dengan menggunakan semua pengalaman manusia dan kemanusiaannya. Oleh karena itu, pengalaman kemanusiaan seseorang dapat diterapkan dalam menjelaskan hal-hal yang berkaitan dengan pendidikan.

Prosedur telaah data yang reliabel dan objektif, dilakukan secara kontinyu, konsentrasi serta reflektif thinking (merenung) terhadap realitas yang dihadapi masyarakat. Adapun telaah yang dilakukan akan menggunakan langkah-langkah sebagai berikut:

\section{Telaah Konsep}

Konsep masyarakat madani ditelaah melalui pendekatan konsep sosial interpretatif dengan mengungkap fakta sosiologis empiris.

\section{Telaah Sosial}

Telaah ini diorientasikan untuk menggambarkan fenomena sosial masyarakat madani secara faktual empiris, kemudian diamati direnungkan secara mendalam sehingga mendapatkan suatu harapan yang utuh dan ideal dari yang dituju oleh tujuan pendidikan.

\section{HASIL DAN PEMBAHASAN}

\section{Masyarakat Madani}

Masyarakat madani adalah masyarakat yang beradab, menjunjung tinggi nilai-nilai kemanusiaan, yang maju dalam penguasaan ilmu pengetahuan dan teknologi. Karakteristik masyarakat madani adalah: bertuhan, damai, tolong-menolong, toleran, keseimbangan antara hak kewajiban sosial, berperadaban tinggi, dan berakhlak mulia.

Sebelum memahami konsep masyarakat madani, ada baiknya harus paham terlebih dahulu arti dari kata tersebut. Masyarakat madani diartikan sebagai masyarakat sipil. Masyarakat madani merupakan format kehidupan sosial yang mengedepankan semangat demokratis dan menjunjung tinggi nilai-nilai hak asasi manusia. Dalam masyarakat madani, warga negara bekerjasama membangun ikatan sosial, jaringan produktif dan solidaritas kemanusiaan yang bersifat non-govermental untuk mencapai kebaikan bersama.

Masyarakat madani juga tidak hanya bersikap dan berperilaku sebagai citizen yang memiliki hak dan kewajiban, melainkan juga harus menghormati equalright, memperlakukan 
semua warga negara sebagai pemegang hak kebebasan yang sama.

Seiring dengan gencarnya sosialisasi tentang tema masyarakat madani (civil society), pada saat ini juga sering disosialisasikan mengenai perlunya masyarakat belajar (learning society) atau biasa juga disebut dengan educational society. Learning society secara praktek sudah dilakukan oleh masyarakat Indonesia, meski belum secara maksimal, namun secara konsep masih meraba-raba. Artinya, bila civil society telah mulai diperkenalkan dan disosialisasikan, maka untuk learning society belum ditemukan konsep yang matang dan fixed, sehingga istilah learning society belum populer didengungkan apalagi dimasyarakatkan (AlRasyidin dan Samsul Nizar, 2005).

Civil society lahir dan berkembang dari sejarah pergumulan masyarakat. Cicero adalah orang Barat yang pertama kali menggunakan kata "societies civilis" dalam filsafat politiknya. Konsep civil society pertama kali dipahami sebagai negara (state). Secara historis, istilah civil society berakar dari pemikir Montesque, JJ. Rousseau, John Locke, dan Hubbes. Ketiga orang ini mulai menata suatu bangunan masyarakat sipil yang mampu mencairkan otoritarian kekuasaan monarchi-absolut dan ortodoksi gereja. ${ }^{5}$ Perbedaan lain antara civil society dan masyarakat madani adalah civil society merupakan buah modernitas, sedangkan modernitas adalah buah dari gerakan Renaisans; gerakan masyarakat sekuler yang meminggirkan Tuhan. Sehingga civil society mempunyai moral-transendental yang rapuh karena meninggalkan Tuhan. Sedangkan masyarakat madani lahir dari dalam buaian dan asuhan petunjuk Tuhan. Dari alasan ini Maarif mendefinisikan masyarakat madani sebagai sebuah masyarakat yang terbuka, egaliter, dan toleran atas landasan nilai-nilai etik-moral transendental yang bersumber dari wahyu Allah. ${ }^{6}$

Masyarakat madani merupakan konsep yang berwayuh wajah: memiliki banyak arti atau sering diartikan dengan makna yang berbeda-beda. Bila merujuk kepada Bahasa Inggris, ia berasal dari kata civil society atau masyarakat sipil, sebuah kontraposisi dari masyarakat militer. ${ }^{7}$ Masyarakat madani adalah masyarakat yang beradab, menjunjung tinggi nilai-nilai kemanusiaan, yang maju dalam penguasaan ilmu pengetahuan, dan teknologi. Allah SWT memberikan gambaran dari Masyarakat Madani dengan firman-Nya dalam Q.S. Saba' ayat 15: Sesungguhnya bagi kaum Saba' ada tanda (kekuasaan Tuhan) di tempat kediaman mereka yaitu dua buah kebun di sebelah kanan dan di sebelah kiri. (kepada mereka dikatakan): "Makanlah olehmu dari rezki yang (dianugerahkan) Tuhanmu dan bersyukurlah kamu kepada-

\footnotetext{
${ }^{5}$ Larry Diamond, Developing Democracy, Toward Consolidation, (2003), Stanford University, h. 278.

${ }^{6}$ A. Syafii Maarif, (2004), Masyarakat Madani, h. 84.

${ }^{7}$ Ibid, h. 84
} 
Nya. (Negerimu) adalah negeri yang baik dan (Tuhanmu) adalah Tuhan yang Maha Pengampun". 8

Masyarakat madani atau civil society secara umum bisa diartikan sebagai suatu masyarakat atau institusi sosial yang memiliki ciri-ciri antara lain : kemandirian, toleransi, keswadayaan, kerelaan menolong satu sama lain, dan menjunjung tinggi norma dan etika yang disepakati secara bersama-sama. ${ }^{9}$ Masyarakat Indonesia masih dalam tahap yang disebut dengan schooling society dan reading society, sehingga perlu upaya keras untuk menuju jenjang lebih tinggi. Jenjang yang harus dituju adalah menjadi masyarakat yang learning society daneducation dan yang lebih tinggi lagi adalah civil society (masyarakat madani). Upaya tersebut bisa dicapai dengan mendukung minat baca masyarakatnya. Dan minat baca akan muncul jika ketersediaan buku-buku di masyarakat lengkap. Seperti yang diketahui selama ini bahwa peranan lembaga pendidikan formal, seperti sekolah, yang baru menjadi perhatian dan mendapatkan tempat di hati masyarakat. Sementara pendidikan informal dan nonformal di Indonesia belum mendapatkan perhatian penuh, andaipun mendapatkan perhatian hanya sedikit saja.

Selama ini banyak anggapan terhadap dunia pendidikan yang terfokus pada pendidikan formal, seperti sekolah saja tidaklah tepat, sebab konsep pendidikan dapat diartikan secara luas. Hal ini dipahami untuk menyebut semua upaya untuk mengembangkan tiga hal, yaitu pandangan hidup, sikap hidup dan keterampilan hidup diri seseorang atau sekelompok orang. Dengan kata lain, untuk menyebutkan peristiwa yang dampaknya ialah berkembangnya pandangan hidup, sikap hidup dan keterampilan hidup diri seseorang atau sekelompok orang. Kalau suatu pendidikan sejak awal dirancang untuk mengembangkan ketiga hal tersebut, maka hal ini disebut sebagai pendidikan formal dan pendidikan nonformal. Sebaliknya, apabila suatu tindakan yang sebenarnya tidak dirancang untuk mengembangkan ketiga hal tersebut, melainkan berdampak demikian, maka peristiwa tersebut dapat dikatakan sebagai pendidikan informal.

Jika dicermati lebih jauh, pemahaman terhadap ketiga jenis pendidikan tersebut diketengahkan untuk memberikan pengertian baru terhadap peran pendidikan formal dan non formal. Dalam pengertian baru ini, maka kegiatan pendidikan tidak hanya terjadi di lingkungan sekolah, akan tetapi juga di lingkungan keluarga dan lingkungan masyarakat. Pada gilirannya nanti tidak hanya pendidikan formal dalam arti sempit, sekolah yang mendapatkan perhatian, akan tetapi juga pendidikan di lingkungan keluarga dan pendidikan di lingkungan masyarakat

\footnotetext{
${ }^{8}$ Departemen Agama, (1992), Al-Quran dan Terjemahnya, h. 685

${ }^{9}$ Din Syamsudin, (1998), Masyarakat Madani, h.12.
} 
(luar sekolah). ${ }^{10}$

Seperti yang dikutip oleh Muljono dari Al-Rasyidin dan Samsul Nizar (2005) mengungkapkan beberapa harapan yang ingin dicapai melalui learning society, khususnya jika dikaitkan dengan perwujudan masyarakat madani, menurut Tim Nasional Reformasi Menuju Masyarakat Madani adalah sebagai berikut:

1. Terciptanya masyarakat yang beriman dan bertakwa kepada Tuhan Yang Maha Esa;

2. Terciptanya masyarakat yang demokratis dan beradab yang menghargai adanya perbedaan pendapat;

3. Masyarakat yang mengakui hak-hak asasi manusia;

4. Masyarakat yang tertib dan sadar hukum, budaya malu apabila melanggar hukum yang melekat dalam semua lapisan kehidupan kenegaraan dan kemasyarakatan;

5. Masyarakat yang percaya pada diri sendiri, memiliki kemandirian dan kreatif terhadap pemecahan masalah yang dihadapi, masyarakat memiliki orientasi yang kuat pada penguasaan ilmu dan teknologi;

6. Sebagai bagian dari masyarakat global, yang memiliki semangat kompetitif dalam suasana kooperatif, penuh persaudaraan dengan bangsa-bangsa lain dengan semangat kemanusiaan yang universal;

7. Terwujudnya tatanan masyarakat yang beradab yang menjunjung tinggi nilai-nilai luhur dan martabat manusia;

8. Mewujudkan masyarakat belajar yang tumbuh dari masyarakat, oleh masyarakat dan untuk masyarakat. ${ }^{11}$

Gagasan tentang learning society semestinya diimbangi dengan kesadaran masyarakat terhadap makna pendidikan, sehingga perwujudan masyarakat belajar akan lebih mudah tercapai.

Harapannya dengan adanya learning societyakan terwujud masyarakat madani sebagaimana yang sedang marak diperbincangkan sekarang. Sekaligus sebagai salah satu alternatif dalam mengatasi masalah yang melanda negeri ini. ${ }^{12}$

\section{Pendidikan Seumur Hidup}

Konsep pendidikan seumur hidup, sebenarnya sudah sejak lama dipikirkan oleh para

${ }^{10}$ Al-Rasyidin dan Samsul Nizar, (2005), Filsafat Pendidikan Islam: pendekatan historis, teoritis dan praktis, Jakarta, Ciputat Press, h. 177

11 Al-Rasyidin dan Samsul Nizar, (2005), Filsafat Pendidikan Islam: pendekatan historis, teoritis dan praktis, Jakarta, Ciputat Press, h. 177

${ }^{12}$ Ibid, h. 190 
pakar pendidikan dari zaman ke zaman. Apalagi bagi umat islam, jauh sebelum orang-orang barat mengangkatnya, Islam sudah mengenal pendidikan seumur hidup, sebagai mana dinyatakan oleh hadits Nabi SAW yang berbunyi:

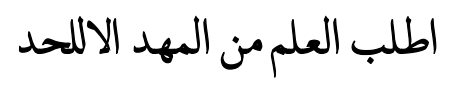

Artinya: "tuntutlah ilmu dari buaian sampai meninggal dunia."

Konsep pendidikan seumur hidup menjadi terkenal dalam dunia pendidikan sejak terbitnya buku karya Paul Lengrand yang berjudul: "An Introduction to Life Long Education" pada tahun $1970 .^{13}$

Konsep pendidikan seumur hidup itu merumuskan suatu konsep bahwa proses pendidikan merupakan suatu proses kontinue, yang bermula sejak seseorang dilahirkan hingga meninggal dunia. Proses pendidikan ini mencakup bentuk-bentuk belajar secara informal, formal maupun nonformal baik yang berlangsung dalam keluarga, sekolah, pekerjaan dan dalam kehidupan masyarakat. ${ }^{14}$

Dasar pemikiran pendidikan seumur hidup ini didasarkan beberapa pertimbangan antara lain:

1. Pada dasarnya pendidikan adalah suatu proses yang berlangsung selama hidup seseorang.

2. Banyak anak-anak yang tidak bisa mengikuti pendidikan formal di sekolah. Padahal mereka memiliki potensi yang perlu dikembangkan yang nantinya dapat berguna bagi dirinya dan masyarakat.

3. Sekolah formal banyak yang tidak sanggup lagi menampung anak-anak usia sekolah untuk mengikuti pendidikan. Akibatnya makin banyak anggota masyarakat dan anak-anak yang tidak pernah merasakan pendidikan di sekolah. Mereka tidak mungkin dibiarkan dalam kebodahan dan keterbelakangan. Mereka perlu ditolong agar dapat ikut berpartisipasi secara aktif dalam pembangunan negara. ${ }^{15}$

Jadi, pemikiran tentang Long life education didasari atas beberapa hal yang telah dikemukakan diatas. Diharapkan dengan adanya konsep Long life education ini semua orang dapat merasakan dan melaksanakan pendidikan seumur hidupnya. Dengan begitu dapat mengurangi tingkat kebodohan dan keterbelakangan masyarakat, dan pendidikan itu sendiri tidak hanya dilakukan di lembaga formal namun juga lembaga informal dan nonformal.

Semua pihak mutlak setuju, bahwa pendidikan amat penting bagi ikhtiar membangun

\footnotetext{
${ }^{13}$ Ekosusilo, Madyo, (1993), Dasar-dasar Pendidikan, Effhar Publishing, Semarang, h. 87

${ }^{14}$ Hasbulloh, (2001), Dasar-dasarIlmu Pendidikan, Rajawali Pers, Jakarta, h. 64

${ }^{15}$ Ekosusilo, op. cit, h. 88
} 
manusia berkualitas, yang ditandai dengan peningkatan kecerdasan, pengetahuan dan keterampilan, karena pendidikan sendiri merupakan wahana strategi bagi usaha untuk meningkatkan mutu kehidupan manusia, yang ditandai dengan membaiknya derajat kesejahtaraan, menurunnya kemiskinan, dan terbentuknya berbagai pilihan dan kesempatan mengembangkan diri menuju masyarakat madani yang merupakan bagian dari tujuan pendidikan nasional.

\section{Kondisi masyarakat saat ini}

Untuk menuju masyarakat madani masih jauh dari harapan, karena kondisi masyarakat yang belum paham betapa pentingnya pendidikan. Betapa pentingnya pendidikan bagi masa depan mayarakat sangat ditentukan oleh kesadaran dan partisipasi masyarakat. Ketika kesadaran dan partisipasi masyarakat kurang optimal maka akan menghambat terciptanya masyarakat madani. Pendidikan seumur hidup saat ini harus menjadi prioritas program pendidikan yang mendapat porsi lebih dari pemerintah yang bukan hanya konsep tapi harus diikuti di dalam tataran implementasi kongkrit dengan dukungan dana yang proporsional sehingga masyarakat bisa akses kapanpun dan dimanapun (anytime and anywhere).

\section{Masyarakat Madani dan Pendidikan}

Di negara manapun pendidikan adalah merupakan aspek penting dan tidak terpisahkan dari program pembangunan. Bagaimana tidak pendidikan merupakan sebuah proses yang menyiapkan sumber daya manusia untuk dapat memiliki kemampuan dan keahlian yang dibutuhkan dalam pengembangan suatu negara. Kemajuan dan kemunduran sebuah negara sangat ditentukan oleh kualitas sumber daya manusia yang dimilikinya. Ini tidak lepas dari tugas bidang pendidikan untuk menyiapkannya.

Perlu diketahui bahwa keberhasilan sebuah kebijakan dan program pembangunan sangat ditentukan oleh tingkat partisipasi masyarakat dalam mengimplementasikan program dan kebijakan tersebut, dan ini tentu harus didukung oleh pendidikan. Tingkat kualitas partisipasi masyarakat sangat dipengaruhi oleh latar belakang pendidikan yang dimiliki oleh masyarakat. Disamping itu, pendidikan juga dipahami sebagai sebuah proses penyiapan warga negara untuk dapat menjalankan tugas dan kewajibannya sebagai warga negara yang baik. Semua ini tidak lepas dari kemampuan bidang pendidikan untuk mencapai tujuannya yaitu mempersiapkan masyarakat untuk dapat menjadi warga negara yang baik yang memiliki keahlian dan pengetahuan yang memadai untuk berperan serta secara proaktif dalam pembangunan.

Selanjutnya pendidikan harus bermuara pada pembentukan masyarakat madani. Istilah masyarakat madani yang identik dengan masyarakat berbudaya oleh Thomas Hobbes dinilai 
sebagai suatu konsep masyarakat yang merujuk kepada masyarakat yang saling menghargai nilai-nilai sosial kemanusiaan yang sarat dengan nilai dan aturan hukum yang diberlakukan dalam suatu masyarakat. Dengan demikian maka upaya penegakan nilai-nilai sosial yang positif dalam suatu masyarakat dapat dijaga dan diwariskan, jika proses pendidikan itu berjalan dengan baik. bagaimanapun juga pencapaian tujuan pendidikan sesungguhnya terkait erat dengan tujuan pembentukan masyarakat madani yang berusaha menegakkan dan menjaga nilainilai sosial kemanusiaan dalam masyarakat.

\section{Pendidikan dan Masyarakat Madani di Indonesia}

Pertanyaan mendasar yang muncul adalah bagaimana dengan pendidikan di Indonesia, sudahkah pendidikan ditujukan pada pembentukan sendi-sendi masyarakat madani? Di Indonesia, beberapa pakar ilmu sosial politik mengemukakan bahwa pembentukan masyarakat madani adalah merupakan bentuk perjuangan kelompok sosial di luar negara untuk memperoleh otonomi. Kelompok tersebut adalah merupakan kelompok marginal yang menikmati ketertindasan politik, ekonomi dan sosial termasuk rasa ketidakadilan dan pemerataan dalam hukum.

Pengalaman bangsa Indonesia ketika keruntuhan Orde Baru merupakan contoh yang sangat signifikan dimana realitas masyarakat madani menuju kebangkitan dapat melakukan perlawanan terhadap negara. Hal tersebut terjadi karena masyarakat merasa tidak memiliki kemerdekaan dalam mengemukakan pendapat dan tidak mampu untuk berpartisipasi secara produktif dalam proses pembangunan.

Dalam konteks pelaksanaan bidang pendidikan dalam kehidupan masyarakat memiliki arti yang sangat penting, karena apa yang menjadi tujuan pendidikan tentu terletak pada pelaksanaan pendidikan itu sendiri. Pelaksanaan pendidikan tersebut yang berlangsung dalam masyarakat secara normal karena tiap-tiap individu dalam masyarakat memiliki kebebasan untuk memperoleh pendidikan yang layak. Jadi pelaksanaan pendidikan tergantung dari kesungguhan masyarakat secara umum untuk memperoleh dan memanfaatkan kesempatan pendidikan yang telah disediakan oleh pemerintah.

Disamping hal tersebut di atas tentu yang paling menonjol dari hubungan antara masyarakat madani dengan program pembangunan bidang pendidikan adalah bahwa pendidikan merupakan sebuah proses untuk menyiapkan masyarakat yang memiliki kepedulian sosial yang dapat dimanfaatkan untuk pembangunan negara. Tentu hal ini sejalan dengan konsep masyarakat madani sebagai sebuah konsep masyarakat yang mampu mengarahkan dan melibatkan masyarakat secara penuh dalam kegiatan pembangunan di segala bidang.

Pendidikan sebagai penyiapan masyarakat diartikan sebagai kegiatan membimbing 
masyarakat sehingga memiliki bekal dasar untuk terwujudnya tatanan masyarakat yang beradab yang menjunjung tinggi nilai-nilai luhur dan martabat manusia. Pembekalan dasar berupa pembentukan sikap, karakter, beradab, menjunjung tinggi nilai-nilai kemanusiaan, yang maju dalam penguasaan ilmu pengetahuan, dan teknologi. Pelaksanaan pendidikan sesungguhnya menjadi penting dalam mewujudkan masyarakat madani di Indonesia, melalui penyiapan sendi-sendi pendukung masyarakat. Jika konsep masyarakat madani dielaborasi dalam konteks pelaksanaan pendidikan maka masyarakat madani dapat diwujudkan atas dukungan program pendidikan yang diterjemahkan sebagai suatu kegiatan penyiapan masyarakat untuk menjadi warga negara yang baik dan sekaligus diterjemahkan sebagai proses untuk mentransfer nilai-nilai dan kebudayaan dari generasi ke generasi berikutnya. Jika konsep masyarakat madani dipahami sebagai sebuah bentuk tatanan masyarakat kewargaan, masyarakat sipil, masyarakat beradab dan berbudaya, maka secara spontan akan sejalan dengan tujuan pendidikan itu sendiri.

\section{KESIMPULAN}

Telaah filsafat dalam pendidikan adalah merumuskan apa dan bagaimana seharusnya tentang pendidikan dengan berusaha merumuskan apa yang dimaksud dengan pendidikan, bagaimana seharusnya tujuan pendidikan. Telaah ini berkaitan nilai-nilai yang berlaku dalam kehidupan manusia, sehingga telaah tersebut harus sampai pada suatu rumusan, apa yang seharusnya terjadi dalam pendidikan yang berlangsung dalam kehidupan.

Telaah filsafat pendidikan Islam adalah sebuah telaah kritis untuk mencari jawaban yang benar terhadap suatu konsep filosofis, interpretasi tentang pendidikan Islam dan implikasinya terhadap pendidikan seumur hidup menuju masyarakat madani.

Pendidikan seumur hidup saat ini harus menjadi prioritas program pendidikan yang mendapat porsi lebih dari pemerintah yang bukan hanya konsep tapi harus diikuti di dalam tataran implementasi kongkrit dengan dukungan dana yang proporsional sehingga masyarakat bisa akses kapanpun dan dimanapun.

Masyarakat madani. yang identik dengan masyarakat berbudaya yaitu masyarakat yang saling menghargai nilai-nilai sosial kemanusiaan yang sarat dengan nilai dan aturan hukum yang diberlakukan dalam suatu masyarakat dalam upaya penegakan nilai-nilai sosial yang positif. 


\section{REFERENSI}

Ali, H.B.H., (1993), Filsafat Pendidikan, Yogyakarta: Kota Rembang.

Baker, A., \& Charris Zubair, A., (1990), Metodologi Penelitian Filsafat, Yogyakarta: Kanisius.

Bandura, A., \& Walters, R.H., (1963), Social Learning and Personality Development, New York: Holt Rinehart and Winston.

Bloom, B.S. (Ed.), (1956), Taxonomy of Educational Objectives, Book I, Cognitive Domain, New York: Longmans Green.

Brubacher, J. S, (1960), Modern Philosophies of Education, Third Edition, Tokyo, Kogakarha

Butler, J.D., (1968), Four Philosophies, New York, Harper \& Row Publishers

Coombs, Philip, (1968), The Word Educational Crisis, New York Oxford University Press.

Cropley, AJ., (1978), Lifelong Education, New York: Pergamon Press.

Dave, R.H., (1973), Lifelong Education and School Curriculum, UNESCO Institute Monographs, Whole No. 1.

(Ed), (1976), Foundation of Lifelong Education, Oxford: Pergamon.

De'Ath, C., (1976), Anthropological and Ecological Foundations of Lifelong Education; In R.H. Dave (Ed.), Foundations Of Lifelong Education, Oxford: Pergamon.

Delker, P.V., (1974), Govermental Roles in Lifelong Education, Journal of Research and Development in Education, 7 - 24 - 34.

Delors, Jacques, Editor, (1998), Education for the Twenty-First Century: Issues and Prospects, Paris: UNESCO Publishing..

Dewey, John (1958), Democracy and Education, New York, The Macmillan Company.

Djudju Sudjana (2001), Pendidikan Luar Sekolah, Bandung, Falah Production.

Dubin, S.S., (1974), The Psychology of Lifelong Learning, New Developments in The Professions, International Review of Applied Psychology, 23, 17 - 31.

Fasli Jalal dan Dedi Supriadi, Editor, (2001), Reformasi Pendidikan Dalam Konteks Otonomi Daerah, Depdiknas-Bappenas, Adicita Karya Nusa. 
Harefa, A., (2000), Pembudayaan Diri, Transformasi Organisasi dan Masyarakat Lewat Proses Pembelajaran, Jakarta: Harian Kompas 1 Agustus. , (2001), Menjadi Manusia Pembelajar, Jakarta: Harian Kompas 1 Agustus..

Illich, Ivan (1972), Deschooling Society, New York: Harper and Row Pupblishers.

Ishak Abdulhak, (2002), Metodologi Pembelajaran Orang Dewasa, Bandung, CV Andira.

Jalaludin, \& Idi A., (1997), Filsafat Pendidikan, Jakarta: Gaya Media Pratama.

Lengrand, P., (1970), An Introduction to Lifelong Education, Paris: UNESCO.

Lindeman, E.C., (1961), The Meaning of Adult Education, Montreal: Harvest House.

Muhadjir, H.N., Pendidikan dan Perubahan Sosial, Edisi V, Rake Sarasin.

Nasution, S., (1995), Sosiologi Pendidikan, Jakarta: Bumi Aksara.

Parkyn, G.W., (1973), Towards a Conceptual Model of Lifelong Education, UNESCO Educational Studies and Documents, Number 12, Paris: UNESCO.

Phenix, P.H., (1964), Realm of Meaning (A Philosophy of The Curriculum for General Education), New York: Mc. Graw Hill Book Company.

Salam, B., (2000), Pengantar Filsafat, Jakarta: Bumi Aksara.

Soedjatmoko, (1995), Dimensi Manusia dalam Pembangunan, Jakarta: LP3ES.

Sudjana, H.D., (2000), Strategi Pembelajaran Pendidikan Luar Sekolah, Bandung: Falah Production.

Suparno, Paul (1997), Filsafat Konstruktivisme Dalam Pendidikan, DIY, Kanisius

Syam, M.N., (1978), Pendidikan Manusia Seutuhnya dan Seumur Hidup, Majalah Pendidikan No. 5 Th. VI, Malang: FIP - IKIP.

Tafsir, A., (1999), Filsafat Umum, Bandung: Remaja Rosdakarya.

Titus, H.H., Smith M.S., Nolan R.T., (Terjemahan 1984), Persoalan-persoalan Filsafat, Jakarta: Bulan Bintang.

Undang-Undang Sistem Pendidikan Nasional, UU RI No. 20 Tahun 2003, Jakarta: Sinar Grafindo. Undang-Undang Dasar 1945 Amandemen (2002). 